\title{
Deflation and Monetary Policy
}

\author{
Barry Eichengreen*
}

The views expressed herein are those of authors and do not necessarily reflect the official views of the Bank of Korea. When reporting or citing this paper, the authors' name should always be explicitly stated.

* Professor, University of California, Berkeley

I am grateful to the Bank of Korea for financial support. Colleagues at the Bank of Korea provided comments on this paper. 


\section{Contents}

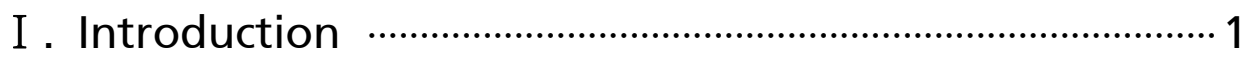

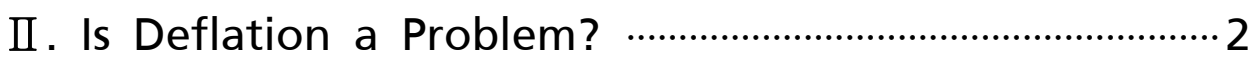

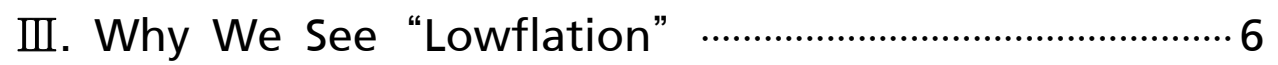

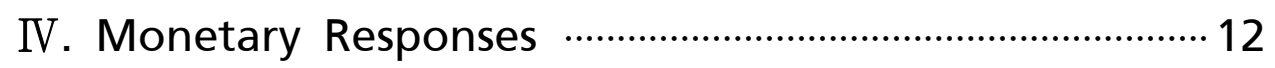

V. Additional Alternatives to Asset Purchases ………....16

VI. Implications for Low Inflation Countries ………….....18

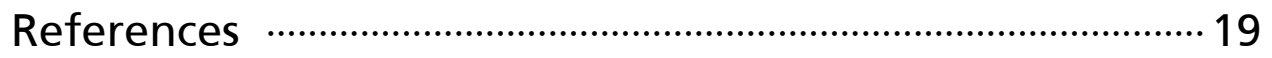




\section{Deflation and Monetary Policy}

Deflation has replaced inflation as the principal challenge for monetary policy in many countries. But influential voices question whether deflation is properly seen as a problem for economic growth and financial stability. They question whether recent experience with deflation is more than a transitory phenomenon associated with the aftermath of the financial crisis and record-low oil prices. And they doubt whether monetary policy can be used to address the deflation problem without creating even more serious risks.

Historical experience as I read it generally confirms that deflation is a problem whose solution should be a priority for central banks. Japan's experience in particular suggests that deflation problems do not solve themselves.

The jury is still out on whether, once deflation is underway, concerted monetary policy action can return inflation to its positive target levels. My own view is that it can. If the policies to date have not achieved their goal, then the central bank or banks in question need to do more. If doing more threatens financial stability, then tools other than monetary policy - so-called macroprudential tools - are appropriate for addressing these risks. If a central bank runs out of government securities to buy or worries about dangerously reducing the liquidity of the government bond market, then it can buy other assets.

The policy response to deflation is straightforward. The only question is whether the relevant authorities will pursue it.

Keywords: Deflation, Quantitative easing monetary policy

JEL Classification: E50, E52 


\section{I . Introduction}

There are several justifications for revisiting one more time the connections between deflation and monetary policy. First, there is the disquieting fact that the Bank of Japan continues to meet with only mixed success in applying an aggressively expansion monetary policy designed to finally vanquish the specter of deflation. Second, there is the fear that other East Asian countries, South Korea and perhaps even China, that have followed a Japan-like development path and now face Japan-like demographics might fall prey to a Japan-like deflation, raising the question of what if anything their central banks can do about it. Third, there is the fact of "lowflation" (inflation that continues to run stubbornly below central bank's self-avowed target), a problem that has seemingly infected much of the advanced-country world. Fourth and finally, there is the debate on Secular Stagnation, raised by Lawrence Summers and others, and the question of whether or there are monetary-policy remedies to the problem. ${ }^{1)}$

It is important to acknowledge that not everyone buys into this framing. Some economists and historians dispute that deflation is a bad thing and that, empirically, it has been associated with poor economic growth. Others question whether the Bank of Japan's recent experience is reason to rethink the connections between inflation and deflation on the one hand and monetary policy on the other; they would insist that the lags between monetary policy and inflation are long and variable (to coin a phrase) and urge observers to give the policy time to work. Still others question the generality and, indeed, the validity of the Secular Stagnation hypothesis and instead attribute the problem of "lowflation" to transitory (conjunctural) factors, such as deleveraging in the aftermath of the financial crisis and weak oil and commodity prices affecting primary-commodity producing and exporting emerging markets.

1) See Summers (2014). 


\section{II . Is Deflation a Problem?}

For much of the $20^{\text {th }}$ century deflation was regarded as a deeply damaging condition to be avoided at all cost. Deflation undermines demand by encouraging households to defer spending, on big-ticket (consumer durable) items in particular, in the expectation that the cost of those purchases will be lower in the future. It leads firms to curtail investment spending on the grounds that the nominal revenues associated with a capital project, insofar as they fall over time, will not justify the current cost of the investment. It depresses employment by raising wages relative to prices and hence the real cost of labor, insofar as nominal wages are slow to adjust downward.2) It creates financial problems for households with long-term debt obligations, whether because they have purchased appliances and cars on the installment plan or because they have home mortgage obligations. It weakens the balance sheets of banks experiencing an increase in nonperforming loans as a result of these problems in the household and corporate sectors. It heightens the cost of servicing inherited debts for governments, which may have to curtail other forms of spending in response.

Worse yet, these problems will tend to be self-reinforcing and self-perpetuating. If consumers hold off spending and firms hold off investing in the expectation of lower future prices, the weakness of demand will tend to validate the expected decline in prices leading to that behavior. Actual declines in prices may lead in turn to expectations of further declines in prices, causing further stagnation of spending and self-reinforcing price declines. Deflation that creates financial distress may lead to further weakness in spending and yet additional deflation. Insofar as interest rates fall in response, central banks may find themselves up against the zero lower bound. Monetary-policy headroom will be limited since interest rates are already low, leaving little scope for them to be cut further when problems arise. There may be little that central banks can do, in other words, to break this vicious spiral. For all these reasons, growth and stability will be casualties when deflation is allowed to occur.

2) A prescient early treatment is Akerlof, Dickens, and Perry (1996). 
This view - that "deflation is a problem" - was heavily informed by the experience of two episodes: the Great Depression of the 1930s, in the United States in particular, where wholesale prices fell by a third between the 1929 peak and 1933 trough; and Japan's deflation and banking crisis starting in the 1990s. Deflation in these two cases, it seemed clear, had a profoundly destructive effect. Thus, the seminal work of Keynes and Fisher on downward wage rigidity and debt deflation was motivated by Great Depression experience. Renewed attention to deflation by the likes of Bernanke and Krugman was then prompted by Japan's experience in the 1990s.3) There being little other comparable experience with deflation in the decade preceding World War I or the second half of the $20^{\text {th }}$ century, these two episodes, the U.S. in the Great Depression and post-bubble-economy Japan, played an outsized role in the analysis that followed.

Objections to this interpretation have been registered on both theoretical and empirical grounds. Theoretically, wages can as easily move down as up, or so critics of the deflationary conventional wisdom suggest. If productivity rises with experience and for other reasons - by, for example, by 2 per cent a year - then prices will have to fall by more than 2 per cent per annum before wages have to be cut in order to maintain the real cost of labor. If prices show a persistent tendency to fall, then wages should become more flexible downward, as employers and workers adjust their practices. Deflation may increase the real burden of principal payments (amortization), but it will reduce the burden of interest payments on liabilities bearing variable rates. In an economy subject to deflationary shocks, there will be an incentive to move to variable rates and shorten the duration of debt contracts.4) Monetary policy headroom may be limited in a low-inflation or deflationary environment, but there are those who doubt the value of monetary policy headroom, arguing that activist monetary policy hurts more than it helps.

It will be apparent that this dispute cannot be resolved by theoretical point-scoring alone. Thus, economists and historians have considered a broader range of country experience and time periods in further efforts to clarify it.

3) The references are to Fisher (1933), Keynes (1936), Bernanke (1999) and Krugman (1998).

4) Thus, farm and home mortgages were shorter in duration in the deflationary late- $19^{\text {th }}$ century United States - though whether this was a function of the price-level environment or the state of development of financial markets is an open question. 
Bordo, Landon-Lane and Redish (2004) look at experience in the late $19^{\text {th }}$ century, when two decades of deflation (1873-93) were followed by two decades of inflation (1893-1913). Concentrating on the experiences of the United States and Germany, they find little evidence that deflation is associated with slower growth. ${ }^{5}$ ) More recently, Borio, Erdem, Filardo and Hofmann (2015) have considered a broad range of countries both in this earlier classical gold standard era and in the $20^{\text {th }}$ and early $21^{\text {st }}$ centuries. They too conclude that there is little evidence that deflation is associated with slower growth.

One characterization of these contradictory findings is in terms of "good" and "bad" deflation.6) Deflation can result from positive supply shocks that raise supply relative to demand. This was the nature of deflation in the $1873-93$ period, when industrialization was spreading, trade was expanding rapidly, and portions of Africa and Latin America were being integrated into the world economy for the first time. This contrasts with the United States in the 1930s and Japan in the 1990s, when deflation resulted from negative demand shocks. The argument, then, is that direct effect of the positive supply shocks dominated any indirect negative effect of the induced deflation. The implication is that deflation is a problem only when it is the result of negative demand shocks.

Of course, this in turn raises the possibility that other consequences of those negative demand shocks, and not their consequences for price-level trends (not their consequences for deflation, in other words), may be the actual culprit. The historical evidence on this question is mixed. On the one hand, Bordo, Erdem, Filardo and Hofmann (2015) argue that negative demand shocks associated with the bursting of credit bubbles, which are in turn accompanied by deflation, and not deflation itself, are the main factor disrupting growth.7) On the other hand, Eichengreen and Grossman (1997), analyzing U.S. experience under the classical gold standard and international experience in the 1930s, allow for distinct roles for both deflation and financial instability. They document separate effects of

5) Bordo and Filardo (2004) and Bordo and Redish (2005) provide related analyses.

6) To invoke the language of Bordo, Landon-Lane and Redish (2004).

7) The authors analyze data for up to 38 economies over as many as 140 years. They find only a weak association between product price deflations and economic growth, but a stronger link between asset price deflations and the performance of the real economy. They show that the impact on growth is higher in the presence of high private debt levels (that debt deflation is a problem) for property price deflations but not goods and services price deflations. 
each, not just during the sharp deflation of the 1930s but also in the $19^{\text {th }}$ century.8)

A prominent instance of deflation that did not result in a persistent slump but, instead, is said to have "cured itself" is 1920-1 in the United States, the episode that is the subject of Grant (2014). Grant argues that market mechanisms, if allowed to work, can adjust smoothly if the authorities resist the temptation to interfere. The problem in the 1930s and during the global credit crisis, in this view, was precisely official interference: jawboning by President Hoover that discouraged wage reductions in 1929-30, and monetary and fiscal stimulus intended to slow deleveraging in 2008-9.

This is an important contention given the prominence of the argument, reflecting the prominence of its principal exponent. In fact, this recession has been considered previously by scholars, such as Wicker (1966), Romer (1988) and Eichengreen (1992), who reach rather different conclusions. Their analyses suggest that the 1920-1 recession and deflation cured themselves only in a very specific sense. Romer's data challenge the notion that the events of 1920-1 rise to the level of a depression, "forgotten" or otherwise. In fact the decline in real GDP was relatively mild, on the order of 2-3 per cent. The downturn resulted not from a major financial disturbance but from the Federal Reserve's decision to tighten monetary policy so as to wring inflation out of the economy; it occurred against the backdrop of inflation rather than deflation, in other words. The economy rebounded quickly not just because of powerful equilibrating forces intrinsic to the market system but because of a series of exogenous supply shocks - the delayed resumption of ocean-going shipping following World War I, which reduced the cost of imported inputs and materials, together with an unusually good weather leading to a bumper harvest. It rebounded quickly because the Fed responded to the deflation by quickly cutting interest rates and injecting ample liquidity into the financial system, a response that sufficed given the source of the initial shock and the limited magnitude of the negative disturbance to which the economy was subjected.9)

8) Eichengreen and Grossman regression growth and prices on a measure of banking crises and the change in the price level, where the former picks up the financial-instability channel while the latter captures any additional effect of deflation; their results point to a role for both.

9) Similar conclusions apply in the United Kingdom, according to Broadberry (1986). 


\section{Why We See "Lowflation"}

The question, then, is whether what we have been observing recently is "good" or "bad" deflation. A first observation pointing in the direction of "bad" deflation is that the problem has arisen in the wake of a major financial crisis that in turn follows a major credit boom. The crisis has induced deleveraging by households, banks and firms, which have sought to work down debt burdens shown by events to be excessive. Households have sought to reduce the ratio of debt to after-tax income, which, in the face of stagnant income growth, they have been forced to do by reducing their spending and paying off debt.10) Firms have sought to reduce levels of debt now recognized as dangerously elevated by limiting their investment spending. ${ }^{11)}$ Banks have sought to repair their balance sheets and raise their capital-asset ratios, where the latter is yet another form of deleveraging, processes which, given the costs of raising new capital and diluting existing shareholders, they have done by limiting their lending.

Progress has not been universal. The change in the household debt-to-income ratio in South Korea rose by 18 percentage points between 2007 and 2014Q2, and there are ongoing worries about levels of corporate and household indebtedness in emerging markets generally. But the ratio of household debt to GDP has declined over the period by 26 percentage points in the United States, 17 percentage points in the United Kingdom, 33 percentage points in Ireland and 13 percentage points in Spain, indicative of considerable spending restraint - that is, of the kind of negative spending response that follows a debt- and credit-fueled financial crisis. Similarly, total financial sector debt as a percentage of GDP has fallen over the same period by 26 percentage points in the U.S., 35 percentage points in the U.K., and 11 percentage points in Japan, indicative of a higher cost of credit and negative shock to the availability of investment finance. ${ }^{12)}$ The negative consequences for spending and demand are hard to dispute. ${ }^{13)}$

10) To put the same point another way, declining real-estate values had a direct negative effect on consumption spending as households that had been financing their consumption with continuous increases in indebtedness secured by rising house values found themselves unable to do so (Hall 2015).

11) A pattern first documented by Myers (1977).

12) Data in this paragraph are from McKinsey Global Institute (2015).

13) A careful analysis of those consequences, together with a relatively pessimistic analysis of progress on deleveraging, is Buttiglione, Lane, Reichlin and Reinhart (2014). 
A second, related observation is that the slowdown in productivity growth afflicting the United States and advanced economies generally since 2005 is not consistent with the "good" inflation story of a positive supply shock.14) Until recently, it might have been argued that that world economy was experiencing a positive supply shock from globalization and/or from the rapid expansion of supply capacity in emerging markets.15) But now, with the dual slowdowns in globalization and emerging markets, that hypothesis becomes harder to sustain. Productivity growth worldwide has fallen from 1 per cent per annum in 1996-2006 to $1 / 2$ per cent in 2007-12 and essentially zero in 2013-15.16) This hardly looks like a positive supply shock. Rather, the weight of the evidence suggests that negative demand shocks are responsible for the low level of interest rates, low level of inflation, and low level of spending afflicting the advanced economies and a growing number of emerging markets.

The fly in this ointment is that real interest rates, in the United States and the advanced economies generally, have been trending downward for several decades. ${ }^{17)}$ (See Figure 1.) The trend started well before the global financial crisis and therefore necessarily reflects more than simply the consequences of that event. This brings us to the Secular Stagnation debate and the hypothesis that observed low rates of interest and inflation reflect chronic deficient demand and, specifically, a chronic excess of global saving over investment. We can think of the equilibrium real interest rate in this framework as the level at which desired saving equals desired investment. That rate may be low because, with slow population and labor-force growth, less investment is needed to raise capital/labor ratios to equilibrium levels and maintain them there.18) It may be low because there has been a secular decline in the relative price of investment goods and because the

14) The timing of changes in productivity growth is documented and discussed by Fernald (2014).

15) That globalization should be a source of disinflation has been argued by Rogoff (2003).

16) These estimates are from the Conference Board's Total Economy Data Base (Conference Board 2015).

17) This is documented by and IMF (2014). An early recognition of the trend is Drsroches and Francis (2006). To some extent, this movement can be interpreted as mean reversion following the unusually high interest rates of the early 1980s (Eichengreen 2015) - but not entirely.

18) This is similarly the implications of the Ramsey optimal-growth model (Ramsey 1928). 
Figure 1: Ten Year Government Bond Yields and Inflation

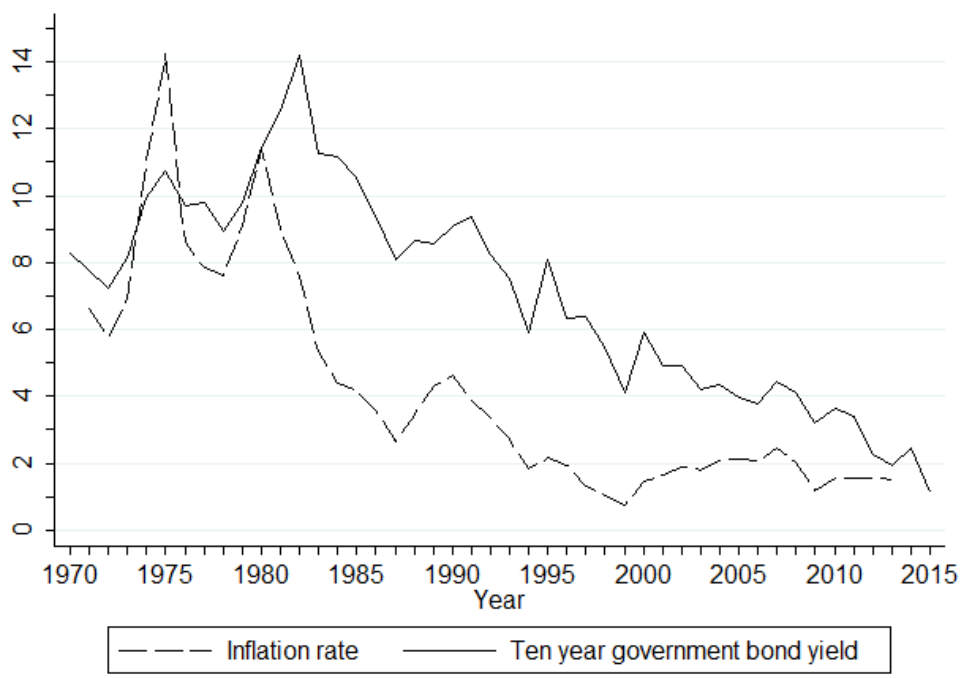

Note: Each time series is composed of a simple average of the corresponding series for the United States, France, Germany and the United Kingdom.

number of investment projects undertaken is relatively insensitive to that price. ${ }^{19)}$ It may be low because of a rise in global saving relative to investment, due to policies first in emerging markets like China and now in Germany (currently the country with the largest current-account surplus in the world).

One question is how low. Hall (2015) concludes from his analysis of the United States that the equilibrium real rate circa mid-2014 may have been as low as -4 per cent. Given the zero lower bound on the nominal interest rate and a low and stable rate of inflation, the result is the self-reinforcing slump known as Secular Stagnation.

There are a number of obvious objections to this logic. First, evidence of a global savings glut (where the global savings ratio is surely what is relevant from the present perspective) is far from overwhelming. The ratio of global saving to global GDP has barely budged in recent decades. (See Figure 2.) Before the crisis,

19) For this implication to follow, the elasticity of substitution between capital and labor must be less than unity. 


\section{Figure 2: Global Savings Rate 1970 to Present}

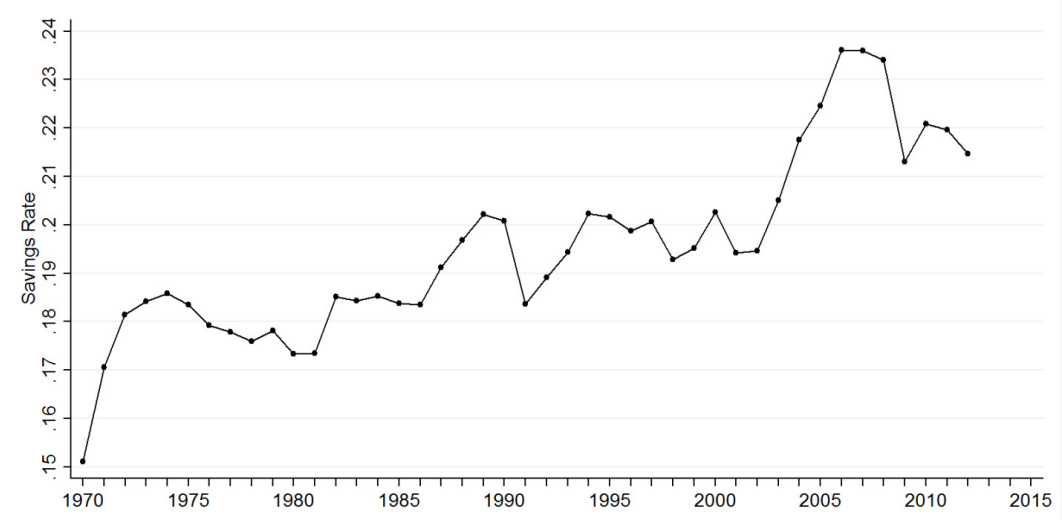

Source: IMF World Economic Outlook Data Base.

higher saving in emerging markets like China was offset by lower saving in the United States and various European countries. ${ }^{20)}$ Going forward, it is clear that savings rates in countries like China and South Korea will come down with increases in the elderly share of the population (which will save less on life-cycle grounds) and with the development of a publicly-funded social safety net. Thus, even if there is a problem of Secular Stagnation due to a global savings glut, it is likely to be of short duration.

Second, the Secular Stagnation argument is predicated on the assumption that the volume of new investment projects insensitive to the cost of capital (as noted in another context above). At a real interest rate of zero, it will be beneficial to undertake any investment project with a positive social rate of return, however small; as Paul Samuelson once put it, it will make sense to level any hill, however small, whose existence raises transportation costs. And what follows from zero interest rates follows from negative interest rates, with a vengeance, implying the existence of powerful forces preventing real interest rates from falling significantly below zero. Weakening those powerful forces, at the same time, will be credit constraints, insecure property rights, and a variety of other factors. As I show in

20) The so-called GIIPS countries in particular. 
Eichengreen (2015), interest rates have, in practice, fallen significantly below zero repeatedly and for extended periods over the course of the last century. The issue from this standpoint is why central banks have been unable or unwilling to raise the rate of inflation to, say, +4 per cent - this question ultimately being the central focus of the present paper, in Section 4 below.

Third, even if there is a shortage of attractive investment projects in the advanced-country world, there are surely plenty of investment projects with significantly positive returns in less developed countries. This point is emphasized by Bernanke (2015). If there is a problem of Secular Stagnation, it therefore reflects the excess of saving over investment and inadequate spending in emerging markets. It reflects the failure of governments there to implement policies and allow the operation of market forces that cause spending to rise more rapidly. Under normal circumstances, one would expect a dearth of attractive investment projects in, say, the United States to prompt foreign investment by the country: that foreign investment should generate capital income that stimulates additional domestic spending, and that encourages additional exports as the dollar weakens against foreign currencies. Failure of these mechanisms to operate presumably reflects the reluctance of other governments to see their own currencies rise and exports fall.

Yet there are also reasons to doubt that quick resort to market-determined exchange rates, implying sharp appreciation of emerging-market currencies relative to those of countries stuck in Secular Stagnation, would do the trick. Consumption reflects habit formation; it is hard to imagine that household consumption in, say, China could be quickly raised from one-third to two-thirds of GDP, whatever happens in foreign exchange markets. Japan's experience suggests that, in conditions of Secular Stagnation, the export response may be weak or nonexistent. ${ }^{21)}$ Bernanke's recommendation, together with the Secular Stagnation diagnosis, implies large capital flows from advanced countries to emerging markets, and emerging markets have not often shown themselves capable of

21) I return to this point and evidence on it below. 
productively investing large foreign inflows. Historically, such inflows have instead fueled credit and consumption booms that ultimately end unhappily.

Finally, with many emerging markets now showing signs of slowing down, it is not clear that they in fact possess an abundance of attractive investment projects at the moment. Those emerging markets that are still growing strongly may possess such projects. But the global savings glut, such as it is, cannot all be devoted to the infrastructure needs of the Indian economy.

A final question is how deflation in fast-growing (or formerly fast-growing) Asian economies like China and South Korea fits into this picture. In both countries, producer prices have been falling and consumer prices, while still rising, have been persistently below the two countries' respective central bank targets. Through March 2015, China had been experiencing producer (factory-gate) price deflation for 36 consecutive months. South Korea similarly had experienced producer price deflation for 37 consecutive months. For China it had long been argued that with a growth rate of 10 per cent per annum and a growth of total factor productivity approaching 4 per cent, this was "good" deflation reflecting ongoing reductions in costs. Chinese growth has now slowed and, predictably (as is typical of other countries, as shown by Eichengreen, Park and Shin 2012), that slowdown has taken the form of a fall in TFP growth more than a fall in the investment ratio. This, together with China's dependence on global export markets, which remain relatively weak, makes the "good" deflation story now harder to sustain. If there are, indeed, any tendencies toward "bad" deflation in China, the country's debt load, which is unusually heavy for an emerging market, is likely to amplify the effects.

For Korea, likewise, the era of rapid TFP growth, emerging market style, that is characteristic of the catch-up phase of economic growth is now over. Korean export growth has been relatively stagnant, again raising fears that what we are observing is the effects of weak (external) demand, making for "bad" deflation. 


\section{Monetary Responses}

Given this lack of consensus on the nature, or for that matter the existence, of the problem, there is necessarily a lack of consensus on how central banks should respond. But posit for the moment that the level of investment will approach that of savings only at a negative real interest rate of 2 to 4 per cent. Can central banks deliver this?

One conceivable option, which a growing number of central banks have resorted given the prevailing low level of inflation, is to push interest rates into negative territory. The Swedish Riksbank was a pioneer, cutting rates for 7-day deposits to -0.25 already in 2010; after then (prematurely) raising its deposit rate, it then moved it back into negative territory, to a full -1 per cent. The Danish central bank was another, cutting interest rates to negative levels on bank deposits over a certain threshold in early 2012 and then, after a respite, cutting them further into negative territory in early 2015 (its deposit rate reached -0.75 per cent in February 2015). The European Central Bank was an additional early mover, in September 2014, when it pushed its deposit rate to -0.2 per cent. The Swiss National Bank adopted its first negative deposit rate since the 1970s in January 2015. While in most cases rates on retail deposits in these countries remained modestly positive (essentially zero), reflecting the reluctance of banks to lose depositors, yields on a range of fixed income securities have slipped below zero. ${ }^{22)}$

The question is how far below zero nominal interest rates can be pushed. It would appear that current policies are testing the limit. A rate on bank reserves below, say, -1 per cent will make it unprofitable for banks to offer positive rates on retail deposits. If they reduce those rates below zero, households will look for other places to park their funds.23) Bank safe deposit box fees are not that high. ${ }^{24)}$

22) Here again Denmark is a test case: in February 2015 at least one Danish bank, FIH Erhvervsbank, announced that it would henceforth charge retail customers to hold funds in their deposit accounts.

23) This was the reaction to the FIH Erhvervsbank announcement, in whose wake the bank experienced significant retail deposit outflows.

24) These observations have led to an interesting literature on abolishing cash as a way of removing this limit on negative interest rates; see Buiter (2003) and Rogoff (2014). Interesting perhaps, but not a development that is likely to happen anytime soon. 
Insofar as investors move their funds into equity and bond markets, of course, this may have the positive portfolio-balance effects stimulating investment and consumption spending that an expansionary monetary policy is supposed to deliver in an environment of Secular Stagnation. But the policy would also do serious damage to the banking system. It raises the possibility that banks, desperate for earnings, might raise lending rates in response. Highly negative rates would also damage the money-market industry, since with rates at zero money market funds would have negative yields after fees, rendering them unattractive to investors. ${ }^{25)}$ And damage to the money market fund industry in turn reduces the liquidity of money and repo markets, in which the funds are significant participants.

The other option is to push the inflation rate up to 2 per cent or higher, given that in an environment of Secular Stagnation the nominal interest rate will not follow. This is the approach of the Bank of Japan under Governor Kuroda, which in April 2013 adopted a program of security purchases quantitative easing and a two-year deadline for reaching its 2 per cent inflation target.26)

The returns on this strategy have been mixed. Japanese core annual inflation was still zero in February 2015, 22 months into the program, once the effect of the country's sales tax hike was removed. Households, not surprising, responded to the failure of inflation to rise (equivalently under the circumstances, the failure of real interest rates to fall) by failing to increase their consumption spending. It may be that core inflation rates are inadequately adjusted for the fall in oil prices that is passed through into the prices of other goods and services. But even with a generous adjustment for the oil price effect, inflation continued to undershoot the BOJ's target.

The key issue is whether a central bank like the BOJ lacks the capacity to raise inflation to 2 per cent in the current environment or whether it simply lacks the will - in other words, that it simply needs to do more in order to achieve its self-professed goal. Arguments for why it lacks the capacity are that the

25) Thus, European money market funds experienced outflows when the ECB reduced deposit rates below zero in September 2014, leading to the closure of several funds.

26) One can see the ECB starting in January 2015 as similarly pursuing this strategy. 
portfolio-balance channel affecting the economy is exhausted, given the already super-low level of interest rates on fixed-income securities. The expectations channel is weakened by divisions on the central bank board, which some would say are inevitable in the face of the extreme policies required by extreme circumstances. Given the resulting limits on forward guidance, exchange rate depreciation is left as the principal mechanism through which expectations of future inflation can be shaped. But the exchange rate channel is undermined by the willingness of other central banks, the ECB for example, to fight fire with fire.

The counterargument is that 2 per cent inflation is still attainable if the central bank is prepared to do more. The BOJ already ramped up the rate of security purchase once, almost by half, in October 2014. Nothing, in this view, prevents it from doing so again, if necessary, or from committing to continue its program of quantitative easing for as long as it takes. Room remains to push the price of risk assets up further through purchases of, inter alia, exchange-traded funds. There is scope for pushing the yen down further through purchases of, inter alia, foreign government securities (intervention on the foreign exchange market). It may take time for exports to respond, reflecting adjustment costs and J-Curve effects, but data from early 2015 suggest that this response is finally underway. ${ }^{27)}$ History, including the history of the 1930s, the last time interest rates in a broad range of advanced countries fell to zero, suggests that deflation can be conquered by sufficiently aggressive central bank action. The problem is not a lack of capacity.

Lack of will or desire may be a problem, however. Central bankers are nothing if not conventional, rendering them hesitant to push unconventional policies too far. Large increases in the size of the central bank balance sheet may create doubts about the credibility of future policy toward inflation, or so central bankers (or at least their critics) may fear. ${ }^{28)}$ Relying on currency depreciation, much less direct intervention in the foreign exchange markets, threatens to antagonize their foreign partners. More purchases of Japanese government bonds (JGBs) reduce the liquidity of the secondary market (since the central bank is a buy-and-hold investor), resulting in a commensurate rise in volatility. ${ }^{29)}$ The BOJ already owns a

27) With the rise in exports has come an acceleration in the rate of increase of industrial production and forecasts of faster economic growth, consistent with the policy working, subject to long and variable lags.

28) For an example of this commentary see Del Negro and Sims (2015).

29) A BOJ staff report in March 2015 warned of these effects of large-scale QE. 
quarter of the outstanding stock of JGBs and is essentially absorbing the entire new issuance.

More generally, central banks may be reluctant to make the kind of large-scale open-ended commitment required to raise inflation to target and reduce real interest rates to -2 per cent or less for fear of creating the conditions for financial instability. Rates on long-term fixed-interest securities will have to fall to low levels as a corollary of the policy, and when the central bank achieves its goal and investors begin to contemplate its exit from the policy - much less the central bank actively shrinking its balance sheet - rates will shoot up, provoking a "taper tantrum." Large leveraged investors may find themselves wrong-footed. In Japan, in particular, every discussion of quantitative easing is accompanied by warnings that another "bubble economy" is being created.

The rebuttal is that the danger of wrong-footing investors can be limited if the central bank clearly telegraphs its intentions. The "taper tantrum" in May-June 2013 was so traumatic precisely because then Fed Chair Bernanke's use of the "t-word" was a surprise; it was not adequately communicated in advance. In contrast, the decision to actually taper in December 2013 was less disruptive because the markets had been prepared by effective communication.

In addition, if financial stability is threatened by leverage or excessive portfolio concentrations in particular asset classes, then the appropriate response is for regulators, including central banks themselves, to clamp down on leverage and portfolio concentrations. This is why central banks have developed the second instrument known as macroprudential policy. Monetary policy can be deployed to "do whatever it takes" to hit the central bank's inflation target, in other words, if macroprudential policy is meanwhile deployed to address financial stability risks. This is just a specific application, to the specific circumstances of deflation, of the Tinbergen Principle that in order to hit two targets - price stability and financial stability - a central bank needs two instruments, and of the Brainard Corollary that in an uncertain environment instruments should be assigned to the target on which they have the strongest impact. ${ }^{30)}$

30) Which means, in the present instance, that monetary policy should be assigned to price stability and macroprudential policy to financial stability. See Tinbergen (1952) and Brainard (1967). 


\section{Additional Alternatives to Asset Purchases}

If asset purchases taken in response to deflation in an environment of Secular Stagnation have undesirable side effects, there are alternatives. One alternative is "helicopter money" - that is, creating additional base money and transferring it directly to households or firms. The central bank can mail a check, in effect an equivalent amount of cash - to each and every household, which will increase spending and, thereby, the price of goods and services directly, instead of operating indirectly via asset markets (insofar as the marginal propensity to spend is high). ${ }^{31)}$ Or to ensure a direct positive impact on spending, one can imagine government undertaking the spending and the central bank financing it by printing money. ${ }^{32)}$

The argument for the policy is that it is designed to enable the central bank to hit its inflation target by stimulating an increased level of spending. If doing so requires injecting additional money into circulation, then this is entirely appropriate under the circumstances (recalling that the central bank can't independently control inflation and money creation). The argument against is that helicopter money places the central bank dangerously close or, even, over the line between monetary and fiscal policy. One might object that there should be no monetary-fiscal-separation purists in crises, just like there are no atheists in foxholes. ${ }^{33)}$ But the central banker's aversion to direct finance of government budget deficits runs deep, insofar as it resonates with concerns over central bank' balance sheets and central bank independence.

Alternatively, governments can undertake additional public spending without additional debt monetization. Under other circumstances this might give rise to

31) The case for this policy is argued by Turner (2013) and Blyth and Lonergan (2014).

32) Woodford (2012) observes that the effects of traditional QE and helicopter money are in fact the same insofar as QE reduces the public debt outside the consolidated public sector, allowing the government to spend more, ceteris paribus, while helicopter money operations in which the central bank finances additional government spending prevent the debt outside the consolidated public sector from rising. The two policies will differ only insofar as they induce different behavior by the government and/or the private sector responds different, perhaps because the consequences for future policy are not perceived as equivalent by the public.

33) As is argued by, for example, Wood (2012). 
fears of crowding out private spending via higher interest rates. But if the circumstance giving rise to deflation is a large excess of desired saving over desired investment, then excess of saving can be used to absorb additional public debt, and finance additional public spending, without driving up interest rates. This, of course, was the argument behind Keynes' original formulation of the liquidity trap - to use modern Hicksian terminology, that there is a substantial range where the LM curve is horizontal, so the IS curve can be shifted right through fiscal action without pushing up interest rates or crowding out private spending.

As for fears over fiscal sustainability, which inevitably arise in connection with Japan, it can be argued following DeLong and Summers (2012) and International Monetary Fund (2014b) that in the current environment of super-low interest rates, governments have generous menus of productive investment projects that will more than pay for themselves with future tax revenues. Using data on public-investment shocks (unexpected increments in public investment spending relative to forecasts), the IMF shows that higher public investment spending typically has no impact on government funding costs. It reduces the debt-to-GDP ratio in both the short and long runs (although only the short-run impact is statistically significant). These impacts are largest in periods of low growth, like that which would accompany Secular Stagnation.

The objection to this line of reasoning is that governments cannot be relied on to invest productively, political pressures being what they are. The fact that Japan initiated a large program of public investment in the 1990s in response to deflation yet saw its public-debt ratio rise rather than falling is regularly invoked in support of this view (Fackler 2009). But, as IMF (2014b) observes, the spurt of public investment was short lived. Public investment spending as a share of GDP peaked already in 1996, after which it headed steadily downward. In addition, announcement of public investment plans regularly exceeded actual implementation by as much as $15-20$ per cent. Different commentators, obviously, will draw different lessons from this experience. 


\section{Implications for Low Inflation Countries}

Deflation has replaced inflation as the principal challenge for monetary policy, at least for the moment. There is little agreement, however, on the gravity of that challenge. Influential voices question whether deflation really is a problem for economic growth and financial stability. They question whether recent experience with deflation is more than a transitory phenomenon, associated with the aftermath of the financial crisis and record-low oil prices, that is already on its way to solving itself. And they question whether, even if deflation remains a problem, monetary policy can solve it without creating side effects in the form of even more serious risks.

Japan's experience and historical experience generally confirm, as I read them, that deflation is a problem whose solution should be a priority for central banks. Japan's experience, in particular, suggests that deflation does not solve itself but, to the contrary, that it can be self-reinforcing, particularly in an environment where desired saving significantly exceeds desired investment. ${ }^{34)}$ The jury is still out on whether, once deflation is underway, concerted monetary policy action like that currently being undertaken by the Bank of Japan can return inflation to its positive target levels.

My own view is that it can. If the policies undertaken to date have not achieved their goal, then the central bank or banks in question need to do more. If doing more threatens to jeopardize financial stability, then tools other than conventional and unconventional monetary policy - so-called macroprudential tools - are appropriate for addressing these risks. If a central bank runs out of government securities to buy or worries about dangerously reducing the liquidity of the government bond market, then there are other assets to buy. If it worries about the side-effects of purchasing these other assets, then it can cooperate with the government on a helicopter drop of money. If that helicopter drop is targeted on productive public infrastructure investments, the latter can proceed without increasing the public debt burden; to the contrary, they can actually reduce it.

The policy response to deflation is straightforward. The only question is whether the relevant authorities will pursue it.

34) And where, as noted, there are obstacles - institutional, political or financial - to equalization through foreign investment. 


\section{References}

Akerlof, G., W. Dickens, and G. Perry (1996), "The Macroeconomics of Low Inflation," Brookings Papers on Economic Activity, Vol. 1, pp. 1-76.

Baba, N., S. Nishioka, N. Oda, M. Shirakawa, K. Ueda, and H. Ugai (2005), "Japan's Deflation, Problems in the Financial System, and Monetary Policy," BIS Working Paper, No. 188.

Bernanke, B. (1999), “Japanese Monetary Policy: A Case of Self-Induced Paralysis?" in R. Mikitani and Adam Posen (eds), Japan's Financial Crisis, Washington, D.C.: Peterson Institute for International Economics, pp. 149-166.

Bernanke, B. (2015), "Why are Interest Rates So Low, Part 3: The Global Savings Glut," Ben Bernanke's Blog, http:/www.brookings.edu/blogs/ben-bernanke/posts/ 2015/04/01-why-interest-rates-low-global-savings-glut (1 April).

Bernanke, B., and H. James (1991), "The Gold Standard, Deflation and Financial Crisis in the Great Depression: An International Comparison," in Glenn Hubbard (ed.), Financial Markets and Financial Crises, Chicago: University of Chicago Press, pp. 33-68.

Blyth, M., and E. Lonergan (2014), "Print Less But Transfer More: Why Central Banks Should Give Money Directly to the People," Foreign Affairs (September/October), http://www.foreignaffairs.com/articles/141847/mark-blythand-eric-lonergan/print-less-but-transfer-more.

Bordo, M., J. Landon-Lane, and A. Redish (2004), "Good Versus Bad Deflation: Lessons from the Gold Standard," NBER Working Paper, No. 10329.

Bordo, M., and A. Filardo (2005), "Deflation in a Historical Perspective," BIS Working Paper, No. 186.

Bordo, M., and A. Redish (2004), "Is Deflation Depressing? Evidence from the Classical Gold Standard," NBER Working Paper, No. 9520. 
Borio, C., M. Erdem, A. Filardo, and B. Hofmann (2015), "The Costs of Deflations: A Historical Perspective,” BIS Quarterly Review (March), pp. 31-54.

Brainard, W. (1967), "Uncertainty and the Effectiveness of Pollicy," American Economic Association Papers and Proceedings, Vol. 57, pp. 411-425.

Broadberry, St. (1986), The British Economy Between the Wars: A Macroeconomic Survey, Oxford: Blackwell.

Buiter, W. (2003), "Overcoming the Zero Bound on Interest Rates with Negative Interest on Currency: Geselle's Solution," Economic Journal, Vol. 113, pp. 723-744.

Buttiglione, L., P. Lane, L. Reichlin, and V. Reinhart (2014), "Deleveraging, What Deleveraging? The $16^{\text {th }}$ Geneva Report on the World Economy," London: CEPR.

Del N., M., and C. Sims (2015), "Central Bank Solvency and Inflation," Liberty Street Economics, New York: Federal Reserve Bank of New York.

DeLong, J. Bradford, and L. Summers (2012), "Fiscal Policy in a Depressed Economy," Brookings Papers on Economic Activity, pp. 233-297.

Desroches, B., and M. Francis (2006), "Global Savings, Investment, and World Real Interest Rates," Bank of Canada Review, pp. 3-17.

Eichengreen, B. (1992), Golden Fetters: The Gold Standard and the Great Depression, 1919-1939, New York Oxford University Press.

Eichengreen, B. (2015), "Secular Stagnation: The Long View," American Economic Association Papers and Proceedings (forthcoming).

Eichengreen, B., and R. Grossman (1997), "Debt Deflation and Financial Instability: Two Historical Explorations," in Forrest Capie and Geoffrey Wood (eds), Asset Prices and the Real Economy, London: Macmillan, pp. 65-96.

Eichengreen, B., D. Park, and K. Shin (2012), "When Fast Growing Economies Slow Down: International Evidence and Implications for China," Asian Economic Papers, Vol. 11, pp. 42-87. 


\section{$21 \quad$ BOK Working Paper No.2015-25 (2015.10)}

Fackler, M. (2009), “Japan’s Big-Works Stimulus Is Lesson,” New York Times, http://www.nytimes.com/2009/02/06/world/asia/06japan.html?pagewanted=all.

Fernald, J. (2014), "Productivity and Potential Output Before, During, and After the Great Recession,” Working Paper, No. 2014-15, San Francisco: Federal Reserve Bank of San Francisco.

Fisher, I. (1933), "The Debt-Deflation Theory of Depressions," Econometrica, Vol. 1, pp. 337-357.

Grant, J. (2014), The Forgotten Depression 1921: The Crash that Cured Itself, New York: Simon \& Schuster.

Hall, R. (2015), "The Routes Into and Out of the Zero Lower Bound," in Federal Reserve Bank of Kansas City, Re-Evaluating Labor Market Dynamics, Kansas City, Missouri: Federal Reserve Bank of Kansas City, pp. 1-35.

International Monetary Fund (2014a), "Perspectives on Global Real Interest Rates," World Economic Outlook, Chapter 3.

International Monetary Fund (2014b), "Is it Time for an Infrastructure Push? The Macroeconomic Effects of Public Investment," World Economic Outlook, pp. 75-114.

Jorda, O., M. Schularick and A. Taylor (2011), "When Credit Bites Back: Leverage, Business Cycles and Crises," Working Paper, No. 2011-27, Federal Reserve Bank of San Francisco.

Keynes, J. M. (1936), The General Theory of Employment, Interest and Money, London: Macmillan.

Krugman, P. (1998), “It's Baaack: Japan's Slump and the Return of the Liquidity Trap," Brookings Papers on Economic Activity, Vol. 2, pp. 137-205.

McKinsey Global Institute (2015), Debt and (Not Much) Deleveraging, New York: McKinsey Global Institute. 
Myers, St. (1977), “The Determinants of Corporate Borrowing," Journal of Financial Economics, Vol. 5, pp. 147-175.

Ramsey, F. (1928), "A Mathematical Theory of Saving," Economic Journal, Vol. 152, pp. 543-559.

Rogoff, K. (2003), "Globalization and Global Disinflation," Paper prepared for the Federal Reserve Bank of Kansas City conference on "Monetary Policy and Uncertainty," Jackson Hole, Wyoming.

Rogoff, K. (2014), "Costs and Benefits of Phasing Out Paper Currency," NBER Working Paper, No. 20126.

Romer, C. (1988), "World War I and the Postwar Depression: A Reinterpretation Based on Alternative Estimates of GNP," Journal of Monetary Economics, Vol. 22, pp. 91-115.

Summers, L. (2014), "U.S. Economic Prospects: Secular Stagnation, Hysteresis, and the Zero Lower Bound," Business Economics, Vol. 49, pp. 65-73.

Tinbergen, J. (1952), On the Theory of Economic Policy, Amsterdam: North-Holland.

Turner, A. (2013), "Debt, Money and Mephistopheles: How Do We Get Out of This Mess?" speech at the Cass Business School.

Wicker, E. (1966), "A Reconsideration of Federal Reserve Policy during the 1920-1921 Depression," Journal of Economic History, Vol. 26, pp. 223-238.

Wood, R. (2012), “The Case for 'Deficit Monetization' and Greater Cooperation between Central Banks and Ministries of Finance," VoxEU.

Woodford, M. (2012), "Methods of Policy Accommodation at the Interest Rate Lower Bound," speech at the Jackson Hole symposium of the Federal Reserve Bank of Kansas City. 


\section{$<$ Abstract in Korean $>$}

\section{디플레이션과 통화정책}

\section{Barry Eichengreen*}

최근 많은 나라에서 중앙은행이 해결해야 하는 주요 과제로서 인플레이션 보다는 디플레이션에 대한 중요성이 커지고 있다. 그러나 디플레이션이 경제 성장과 금융안정에 문제가 될 것인지에 관하여 아직 의견일치가 이루어지지 않고 있다. 디플레이션이 문제가 되지 않는다는 입장에서는 최근 경험하고 있는 디플레이션이 저유가 등 일시적인 요인 외에 구조적 요인에 기인하는지가 확실하지 않음을 지적한다. 다른 한편에서는 통화정책으로 디플레이션 문제를 해결하는 과정에서 보다 심각한 위험이 초래될 수 있음을 우려하고 있다.

일본의 사례 등 역사적인 경험에 비추어 볼 때, 디플레이션은 자체적으로 해결될 수 없다는 점에서 중앙은행이 해결책을 모색해야 하는 주된 문제라는 것이 본고의 입장이다. 또한 아직 불확실한 점은 있으나 만약 디플레이션이 이미 진행되고 있는 상황이라면, 중앙은행이 적절한 정책 운영을 통해 디플레이션 문제를 해소할 수 있으리라고 본다. 만약 지금까지의 중앙은행 정책이 디플 레이션을 해소하는 데 미흡하였다면, 추가적인 정책 노력을 하여야 한다고 본다. 이 과정에서 금융안정이 저해된다면 거시건전성 정책 수단을 활용함이 적절할 것이다. 또한, 중앙은행의 국채 매입이 국채시장 유동성을 지나치게 위축시킬 우려가 있다면, 국채 이외의 자산을 매입함으로써 대처할 수도 있을 것이다.

이와 같이 디플레이션 발생시 이에 대응한 정책수단은 명확하므로, 중앙은 행은 동 문제 해결을 위한 정책을 적절하게 운영하는 것이 긴요하다.

핵심 주제어: 디플레이션, 양적완화정책

JEL Classification: E50, E52

\footnotetext{
* University of California, Berkeley 교수

이 연구내용은 집필자의 개인의견이며 한국은행의 공식견해와 무관합니다. 따라서 본 논문의 내용을 보도하거나 인용할 경우에는 집필자명을 반드시 명시하여 주시기 바랍니다.
} 